$<$ Editorial $>$

\title{
A 型肝炎の最近の動向と合併症
}

\author{
佐田 通夫 ${ }^{11} \quad$ 長尾由実子2)
}

索引用語： A 型肝炎 hepatitis A 肝外合併症 extrahepatic manifestation

\section{はじめに}

A 型肝炎ウイルス (hepatitis A virus: HAV)はピ コルナウイルス科のヘパトウイルス属に分類されてい る1). 他のピコルナウイルス科のウイルスと異なり, 肝藏に強い親和性を持っている。通常, 感染細胞に対 して細胞障害効果 $(\mathrm{CPE})$ を示さないが, 最近 CPE が みられる変異 HAV の存在が報告され, 重症肝炎との 関連性が示唆される2 4). HAV は A 型肝炎発症前後 の患者䔬便中に多量に排泄され、これがまた感染源に なる. 血中や唾液中にもこのウイルスは検出され る5 7). 主な感染様式は悠便中に排泄されたウイルス で污染された飲食物を介しての経口感染, あるいは飲 食物を介さない直接の経口感染経路である ${ }^{8)}$. 肝細胞 あるいはクッパー細胞で増殖した HAV は胆管, 胆汁 を介して腸管内に移行した後, 粪便と共に体外に排出 され，次の感受性者の感染源となる9 11)。したがっ て, 大規模な集団発生には上下水道などの衛生環境の 不備が関与していることが多いので, わが国では第 2 次世界大戦前まで常在の伝染病であったと考えられて いる. その後の衛生環境の整備によって最近では, 爆 発的な集団発生はみられなくなっている４0歳未満の 住民はほとんど HAV 抗体を保有していない12)とい う結果からも，わが国では HAV の浸淫状況がかなり 低いことが理解できる. しかし, 決して A 型肝炎が なくなったわけではないことは, 散発性急性肝炎の調 查から知ることができる. 矢野らの共同研究によれ ば, 散発性急性肝炎に占める A 型肝炎の割合は 48.4 \%と最も高い值を示している13). 一方, 最近の A 型

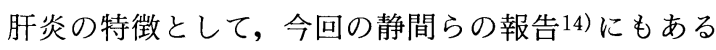
ように, 罹患年齢の上昇とそれに伴う重症例の増加が 挙げられる15,16). A 型肝炎の重症化は二つに分類で きる.一つは $\mathrm{A}$ 型肝炎そのものの重症化, 劇症化で あり15,17 19), 他の一つは肝外合併症 ${ }^{20)}$ の出現による

1) 久留米大学医学部第 2 内科

2)久留米大学先端癌治療研究センター肝癌部門
全身状態の悪化である．今回の林らの報告21)にもあ るように，A 型肝炎に合併する肝外合併症の認識と その対処は熟知しておくべき重要事項である。一方, 生活環境や社会現象の変化は $\mathrm{A}$ 型肝炎の感染様式に も変化をもたらしているようである. 海外渡航者の増 加は輸入肝炎としての A 型肝炎の存在を認識させる ことになったし, HAV の高浸淫地域から輸入される 生鮮食品が感染源となっている可能性がないかを検討 する必要性があるようにも思われる。

わが国でも HAV に対しての感染予防にワクチンを 使用できる状況になった 22,23). ワクチンによる大規 模な感染予防効果が検討され, その有効性と安全性が 報告されている。わが国にも $\mathrm{A}$ 型肝炎をなくすため に, 能動免疫による感染予防を積極的に行っていかな ければならないハイリスクグループが存在する.

ここでは現状の A 型肝炎についての解析と今後の 展望について述べたい.

\section{発生状況と感染様式}

感染症予防に関する法律が改正され，ウイルス肝炎 は発生動向の把握・提供をすべき疾患となったが，A 型肝炎の正確な年間患者発生数やその感染様式, そし て病態を知ることは困難である。国立病院急性肝炎研 究班の調査によると, 1980 年から 1997 年までのわが 国における散発性急性肝炎の発生状況は, 総患者数 3,052 例で, 原因別では $\mathrm{A}$ 型急性肝炎が 1,321 例 (43.3\%) と最も多くを占め, 続いて B 型 751 例 (24.6 \%), C 型 249 例 (8.2\%), そして非 A 非 B 非 C 型が 731 例 (24\%)であったことが示されている.A 型急性 肝炎は最も多く, 日常的な疾患としての認識が必要で ある。しかしながら，爆発的な大流行や集団発生がみ られなくなったことは間違いない. Kiyohara ら 12) は, 1994 年に 11 都道府県で採取した 2,708 血清検体 について HAV 抗体を測定している，0９1歳の年 齢別抗体保有率をみると，1973年および1984年に実施 された抗体保有率に比較して, 抗体保有者が高龄層に シフトする現象が認められている.さらに 40 歳以下 
の多く (99\%以上) が，HAV 抗体陰性者であったこと も示され，先進国の多くが類似の抗体保有率を示すこ ともよく知られている.このような若い年齢層での抗 体保有率の低下は HAV の浸淫度が低くなっているこ とや大流行がなくなったことを示すものである，A 型肝炎の発生状況をみると以前から指摘されているよ うに，冬から翌年の春先にかけて多発し，季節発生が 認められる24,25)。しかしながら 1 年を通して，とぎ れることなく患者が発生しているようであり，このこ とは感染様式の多様性を表しているのかもしれない. 季節発生について, 日野はこの時期に多食される生力 キ摄取との関連を case control studyによって明らか にした ${ }^{24)}$. HAV が貝類に濃縮され存在することがそ の要因に挙げられる，北橋ら26) は，千葉市美浜区に 自生している生力キを 1997 年 4 月から 1998 年 3 月ま での 1 年間, 毎月採取して HAV の検出を試みた。 112 検体中 2 検体に HAV RNA が検出され, さらに この 2 検体はともに HAV 遺伝子型分類の $1 \mathrm{~A}$ 型で あり，1検体の塩基配列は 1995 年に千葉市で集団発 生した時の $\mathrm{HAV}$ と全く一致していたと報告してい る.

感染様式の多様性を示唆する次のような報告があ る。欧米諸国では 1990 年代に入り，A 型肝炎の危険 因子として男性同性愛者・両性愛者 (men who have sex with men: MSM)の性行為が指摘されるように なり，MSM における A 型肝炎の流行が指摘されて いる.アトランタでの A 型肝炎流行の報告によれば, 患者の $75 \%$ が男性同性愛者であったとされている27)。 MSM 間での oral-anal-contact が感染経路に挙げら れている．わが国では Ishida らが HAV 感染者にお ける A 型肝炎の流行を報告している28)．HIV-1 陽性 者 550 例のうち HAV 感染者は 13 例で，全例男性同 性愛者であったとしている. Kojima らによれば HIV 感染者の $\mathrm{A}$ 型肝炎の臨床像は通常の場合と同じで, 肝機能異常を認め, IgM 型 HAV 抗体も上昇すると している29)。その中で，男性同性愛者の多くは，不 特定のパートナーと性交涉をもっていることから， HIV と共に HAV の感染拡大にとってハイリスクグ ループであると説明している。また Koibuchi ら30) は，HIV-1 陽性の A 型肝炎の男性患者から採取した $\mathrm{HAV}$ 遺伝子の解析を行ったところ，13 例中 10 例の VP $1 / 2 \mathrm{~A}$ 領域が同じ塩基配列であったと述べている.

一方，東南アジアをはじめとする熱帯，亜熱帯地域 はHAV の高浸淫地域として知られる。このような地
域への渡航者が年々増加していることや，海外との食 糧流通が盛んになり, 多くの生鮮食品がわが国に入っ てくるようになったことなどが最近の A 型肝炎の発 生要因になっている可能性もあり，今後の検討が必要 である。1 年を通じて患者発生が絶えない原因には， 上記のようなことが関係しているかもしれない. 加え て年間を通して A 型肝炎が発生していることを考え る上で，幾つかの興味ある結果が示されている，一つ はHAV の糞便中への排泄期間についての研究であ る31). Yotsuyanagi ら 31 ) は, 散発性 A 型肝炎患者 10 例について䔬便中から HAV RNA が検出される期間 をRT-PCR 法を用いて検討している. 発症後 3 力月 を経過しても，検出される例があったことを示してい る. 最近 Chitambar ら 32$)$ は，67 例の A 型肝炎患者 (インド人)のうち $40 \%$ に便中に A 型肝炎ウイルス (HAV RNA) が検出されたと報告している.1例の便 を HAV 非感染アカゲザルに移植したところ，血清 ALT は正常であったが，3 日〜50日後まで便中に HAV RNA が認められたことを示した。アカゲザル が血清学的に抗 HAV-IgM が認められたのは 31 日目 であった。このように PCR 法を用いた早期診断法の 確立は，感染拡大の防止や予防対策として，HAV の 感染ルートの解明に有用である。我々も，発症後 2 カ月目の糞便検体から培養細胞を用いて HAV の分離 培養に成功している. 一方, 腸管内に存在する $\mathrm{HAV}$ の中和抗体と考えられる分泌型 IgA HAV 抗体が胆汁 中に発症後 2 週目から少なくとも 6 力月目までは検出 されることを我々は報告した。さらに，DeSerresら33) は, HAV が井戸水への混入の元になった戴尿保存場 所から $60 \mathrm{~m}$ 離れた井戸水からも HAV RNA が検出 され，6力月後の大腸菌が検出されなくなった時期に も HAV RNA が検出されたとの報告をしている。こ のように患者から排出された HAV は長い期間自然界 に留まっているようであり，これが HAV の感染拡大 や患者発生に関与する可能性も考えなければならない のであろう。

\section{$A$ 型肝炎の病態の変化}

HAV 抗体保有率の変化は A 型肝炎の病態にも影 響をもたらしている。村岡15) は，1979 年から 1980 年 の間に発生した散発性 A 型肝炎 269 例をもとに, 重 症化因子を検討した。その結果，加齢と他の肝疾患の 合併が重症化因子として重要であることを明らかにし た。また神代ら 16) は, 50 歳以上と末満の A 型肝炎を 比較することで, 重症化の要因に加齢が重要であるこ 
とを示した。そこで我々は，高齢の HAV 抗体陰性 者, すなわち HAV 感受性者が増加することによっ て, A 型肝炎の罹患年齢が上昇し，その結果，重症 例や劇症化例が増加する可能性があることを示唆して きた。今回の静間らの報告をみても，我々の予想が間 違っていなかったと言えるようである。

我々は, 84 歳男性の $\mathrm{A}$ 型劇症肝炎例を経験し た ${ }^{19)}$. 食欲不振と全身倦急感で発症し, 近医に入院 し加療中であったが，入院 4 力月後に肝性昏睡 IV 度 となり，当院に入院となった。第 14 病日目に他界さ れたが，その後に IgM 型 HAV 抗体が陽性であるこ とが判明し， A 型劇症肝炎であることがわかった。 このような高齢者は, A 型肝炎に罹患する可能性は 低いと認識されているために診断や対応が遅れた可能 性を反省すべき症例と思われる。

その他の重症化の要因としては, 生体側因子として 慢性肝疾患の存在, 常習飲酒, 肝外合併症の出現など があり，ウイルス側因子としてはCPEを有する $\mathrm{HAV}$ やウイルス変異株, 他の肝炎ウイルスの重感染 などを挙げることができる.

\section{$A$ 型肝资の肝外合併症}

A 型肝炎の臨床経過は劇症化 $15,17 \sim 19)$, 肝内胆汁う つ滞例34), 治癒遷延例35) そして今回の報告にもある 急性腎不全をはじめとする肝外合併症 20 をを認める例 以外は良好であり，慢性化もない。

臨床経過で知っておくべき重要事項の一つとして, HAV の感染を契機に起こる種々の肝外合併症があ る.その中で比較的発症頻度が高く, 重篤なものに腎 障害と造血器障害が挙げられる。

腎障害は A 型肝炎患者の 20～30\%にみられるとさ れているが, 蛋白尿, BUN, クレアチニンの上昇の みで気づくものから, 透析治療を必要とする急性腎不 全の状態まで様々である，発症機序はまだ明らかにさ れておらず，障害部位も腎系球体值と急性尿細管壊死 の両方が報告されている。この障害部位の違いは，同 じ $\mathrm{A}$ 型肝炎であっても発症要因の違いに起因してい るのであろう.今までに腎障害の原因としては免疫複 合体, エンドトキシン血症, ウイルスの直接障害, 循 環障害, 肝障害によって出現する種々の代謝産物, 解 熱剂の使用などが挙げられている。

$\mathrm{A}$ 型肝炎にみられる造血器障害は稀な合併症とさ れているが，生命予後を左右する状況にもなるため， その診断と加療には細心の注意が必要である. 合併す る血液疾患としては, 赤芽球痨 $(\mathrm{PRCA})$, 再生不良性
貧血, 溶血性貧血, 特発性血小板減少性紫斑病などが 報告されている. 1955 年, Lorenzo ら36) は, ウイル 不性肝炎に罹患後 4 週目に発症した再生不良性貧血の 1 例を報告した。造血器障害の機序も不明であるが, Bush ら37) は, HAV と骨䯣細胞を混合培養すること によって, progenitor cell の分化増殖を HAV が抑制 することを証明した。この中で IFNや TNF などの サイトカインはこの現象は関与しておらず，HAVの 骨髄細胞への感染が直接関与している可能性を示し た。一方，我々が経験した PRCA にはプレドニゾロ ンが奏功していることから 38 , PRCA の発症機序に は HAV の直接的な関与と共にウイルス感染によって 惹起される何らかの免疫異常が関与している可能性が ある. 最近, 我々は赤芽球低形成と自己免疫機序によ る血小板減少，そして急性腎不全を合併して死亡した A 型肝炎の 1 例を経験した ${ }^{39)}$. 骨髄所見は PRCA に 類似し, PA IgG の高值と免疫複合体の上昇を認め, 自己免疫機序の関与による血小板減少が考えられた。 また貧血の進行には溶血の合併が示唆されたＡ型 肝炎に合併する造血異常の発症機序を考える上で興味 深い 1 例である。

\section{$A$ 型肝炎ワクチン}

ワクチンによる感染予防を示す多数の報告がある. しかし, HAV に曝露後のワクチン効果に関する検討 は少ない40). Robertoson ら41) は, 2 匹のチンパンジ 一にウイルスに曝露後, 1 日目と 3 日目にワクチンを 接種したところ，1匹は感染が証明されず，1匹は軽 度の ALT の上昇がみられたが，接種しなかった 2 匹 は A 型肝炎を発症したとしている. D'Hondt らのマ 一モセットを用いた検討では42), ウイルスに曝露 48 時間後にワクチンを接種すると，低用量のワクチンを 投与された 4 匹中 3 匹は発症したが，コントロール群 に比べると便中へのウイルスの排泄量は少なく期間も 短かったとしている.ささらに高用量のワクチンを接種 された 3 匹では $\mathrm{A}$ 型肝炎の発症を防御できたとして いる. ヒトの場合, ウイルス曝露後 2 週以内では, ヒ ト免疫グロブリンによって $90 \%$ 以上の防御ができる ことから 43$)$, 曝露後の予防には上卜免疫グロブリン がワクチンより有効とも考えられるが, ワクチンによ る感染防御効果についても検討が必要である44).

集団内における感染防御効果の検討では, A 型肝 炎の高浸淫地域であり, 幼小児期に既にその多くが A 型肝炎に罹患する夕イ国に打いて, 4 万人以上の規 模で小児を対象とした不活化 A 型肝炎ワクチンの安 
全性と予防効果が検討されている。これによればワク チン群はコントロール群に対して確実に感染防御効果 が認められること，また副作用の面においても問題が なかったことが報告されている45)。 また Werzberger ら46)も, A 型肝炎の頻発する地域において, プラセ ボとの二重盲検比較試験を行った結果, ワクチン群 (519人)では 1 例の発症もなかったのに対して, プラ セボ群(518人)では 25 例が発症したと報告している.

ワクチン接種後の抗体価の持続に関しては, Tana$\mathrm{ka}$ らは $0,1,6$ 力月の 3 回筋注し, 1 回 $0.5 \mu \mathrm{g}$ 以 上の接種では全例が初回接種後 3 年以上は感染防御可 能な $100 \mathrm{mIU} / \mathrm{m} l$ 以上を示したとしている23).また Berger ら 47$)$ は，360〜 720 ELISA 単位を 3〜4 回接種 した場合， 3 年間は $\mathrm{A}$ 型肝炎の予防が可能であると している.このように感染防御効果扔よび抗体価の持 続に関しては, 現在のワクチンでかなりの効果が期待 できると思われる。ささらに最近 Koff 48 は， A 型肝炎 や C 型肝炎を有する B 型肝炎の重複感染は, 単独の ウイルス肝炎よりも重症な肝障害を引き起こすため, $\mathrm{HAV}$ と HBV のワクチンは, HCV 感染と診断され た患者にはルーチンに投与されるべきであると述べて いる.

海外へ旅行するような場合, 短期間のうちに感染予 防効果を得る必要があるときに関してはどうであろう か. わが国で開発されたワクチンでは, 1 回接種後 2 週目ですでに $95.5 \%$ の陽転率が認められることから， 時間がない場合でも予防は十分可能であると考えられ る.また海外では Poovorawan ら 49) は, 1 回の接種 によって 1 年以上にわたり予防可能な抗体価が持続す ると報告している.

今後わが国においても，A 型肝炎のハイリスクグ ループを設定し, 積極的なワクチンの活用が重要では ないかと思われる。

おわりに

A 型肝炎の現状を把握すると共に, 絶滅に向けて のさらなる努力が必要である。

\section{文 献}

1) Nainan OV, Brinton MA, Margolis HS : Identification of amino acids located in the antibody binding sites of human hepatitis A virus. Virology 191:984-987, 1992

2) Zhang $\mathrm{H}$, Chao SF, Ping LH, et al: An infectious cDNA clone of a cytopathic hepatitis A virus : genomic regions associated with rapid replication and cytopathic effect. Virology 212:686-697, 1995

3) Beneduce F, Pisani G, Divizia M, et al : Complete nucleotide sequence of a cytopathic hepatitis A virus strain isolated in Italy. Virus Res $36: 299-309,1995$

4）藤原慶一, 横須賀収：A 型肝炎の重症化と HAV RNA. 臨床消化器内科 $12: 553-557,1997$

5）佐田通夫, 瀬戸山浩, 安倍弘彦, 他：A 型肝炎 ウイルスの唾液中排泄について。肝臟 $25: 423$, 1984

6) Cohen JI, Feinstone S, Purcell RH : Hepatitis A virus infection in a chimpanzee : duration of viremia and detection of virus in saliva and throat swabs. J Infect Dis. $160: 887-890,1989$

7) Setoyama H, Sata M, Suzuki H, et al : Secretory IgA anti-HAV in saliva of hepatitis A patients. Hepatol Res 11:12-18, 1998

8）谷川久一, 佐田通夫：A 型急性ウイルス肝炎. 最新内科学大系 $48: 97-118,1991$

9) Shimizu YK, Mathiesen LR, Lorenz D, et al : Localization of hepatitis A antigen in liver tissue by peroxidase-conjugated antibody method: light and electron microscopic studies. J Immunol 121 : 1671-1679, 1978

10) Shimizu $Y K$, Shikata $T$, Beninger $P R$, et al : Detection of hepatitis A antigen in human liver. Infect Immun $36: 320-324,1982$

11) Taylor M, Goldin RD, Ladva $S$, et al : In situ hybridization studies of hepatitis A viral RNA in patients with acute hepatitis A. J Hepatol $20: 380-387,1994$

12) Kiyohara $T$, Satoh $T$, Yamamoto $H$, et al : The latest seroepidemiological pattern of hepatitis A in Japan. Jpn J Med Sci Biol 50:123131, 1997

13）矢野右人：散発性急性肝炎における HEV の関 与. 新興・再興感染症研究事業非 A 非 B 型肝炎 の臨床的総合研究. 平成 12 年度総括・分担研究報 告書 $106-108,2001$

14）静間 徹, 小幡 裕, 橋本悦子, 他: 当院での過 去20年間に扔ける A 型肝炎の臨床・疫学的検討. 肝臟 $42: 581-589,2001$

15）村岡晴雄：A 型肝炎の重症化因子に関する臨床 病学的研究. 日消誌 $87: 1383-1391 ， 1990$ 
16）神代龍吉，佐田通夫，鈴木 宏，他：高齢者層の A 型肝炎の検討. 肝蔵 29：457-462, 1008

17）安倍弘彦，佐田通夫，瀬戸山浩，他：広汎性肝壊 死を呈し，腎不全を併発し死亡した A 型肝炎の 一例. 臨床と研究 $58: 3950-3954,1981$

18) Sata M, Nakano H, Tanaka E, et al : Analysis of serum hepatitis A virus antibody response in different courses of hepatitis A virus infection. J Gastroenterol $31: 812-817$, 1996

19）石井邦英, 神代龍吉, 佐田通夫, 他：高齢発症の $\mathrm{A}$ 型劇症肝炎の一剖検例. 日本救命医療研究会 雑誌 $12: 89-93,1998$

20) Sata M, Nagao N : Symposium on clinical aspects in hepatitis virus infection. 6. Hepatitis virus and extrahepatic manifestions-skin, mucosa, muscle, and hematopoietic organs. Intern Med 40:185-189, 2001

21）林 鈞貴, 後藤 隆，小松真史，他：急性尿細管 壊死を来した A 型急性肝炎の 1 例. 肝臓 42 : 600-606, 2001

22) Fujiyama $S$, Iino $S$, Odoh $K$, et al: Time course of hepatitis A virus antibody titer after active and passive immunization. Hepatology $15: 983-988,1992$

23) Tanaka E, Sata M, Nakano H, et al : Antibody response to inactivated hepatitis $\mathrm{A}$ vacine. Hepatol Res 9:103-113, 1997

24）日野和彦：散発性 A 型肝炎の季節発生とその要 因についての検討. 肝臓 28：853-862，1987

25）松行真門，弓削 建，小野栄一郎，他：小児散発 性 A 型肝炎の臨床像。日小児会誌 $91 ： 1654-$ 1659, 1987

26）北橋智子，田中俊亮，宇田川悦子：千葉市沿岸の 自生カキからの HAV, SRSV，アストロウイル ス遺伝子の検出. 感染症誌 $73: 559-564,1999$

27) CDC: Hepatitis A vaccination of men who have sex with men-Atlanta, Georgia, 19961997. MM-WR47 : 708-711, 1998

28) Ishida $T$, Nakamura $T$, Ajisawa $A$, et al : Outbreak of hepatitis A virus infection among HIV-1 seropositive men who had sex with men. Jpn J Infect Dis $52: 131-132,1999$

29) Kojima T, Tachikawa N, Yoshizawa S, et al : Hepatitis A virus outbreak; a possible indicator of high risk sexual behavior among HIV-1 infected homosexual men. Jpn J Infect Dis 52 : 173-174, 1999

30) Koibuchi $T$, Ishida $T$, Nakamura $T$, et al : Genetic analysis of outbreak of hepatitis $A$ virus infection among HIV-1 seropositive men. Jpn J Infect Dis 52:249-250, 1999

31) Yotsuyanagi H, Koike K, Yasuda K, et al : Prolonged fecal excretion of hepatitis $A$ virus in adult patients with hepatitis $\mathrm{A}$ as determined by polymerase chain reaction. Hepatology 24:10-13, 1996

32) Chitambar SD, Joshi MS, Sreenivasan MA, et al: Fecal shedding of hepatitis $A$ virus in Indian patients with hepatitis $\mathrm{A}$ and in experimentally infected Rhesus monkey. Hepatol Res $19: 237-246,2001$

33) De Serres G, Cromeans TL, Levesque B, et al : Molecular confirmation of hepatitis A virus from well water: epidemiology and public health implications. J Infect Dis $179: 37-43$, 1999

34）安倍弘彦，佐田通夫，瀬戸山浩，他：肝内胆汁う つ滞を呈したA 型肝炎の 3 症例. 肝臓 22 ： 1445-1452, 1981

35) Sjogren MH, Tanno H, Fay O, et al : Hepatitis A virus in stool during clinical relapse. Ann Intern Med 106:221-226, 1987

36) Lorenz E, Quaisar K: Panmyelopathie nach hepatitis epidemica. Wien Med Wschr 105: 19, 1955

37) Busch FW, de Vos S, Flehmig B, et al : Inhibition of in vitro hematopoiesis by hepatitis $\mathrm{A}$ virus. Exp Hematol 15:978-982, 1987

38) Ide T, Sata M, Nouno R, et al : Clinical evaluation of four cases of acute viral hepatitis comlicated by pure red cell aplasia. Am J Gastroenterol 89：257-262, 1994

39）草場信秀, 吉田 博, 大久保文彦, 他：赤芽球低 形成と自己免疫機序による血小板減少を合併した A 型肝炎. 臨床免疫 41:739-744，2000

40) Kuramoto I, Fujiyama S, Odoh K, et al : Long-term follow-up of antibody titer after hepatitis A vaccination. Int Hepatol Commun $1: 194-199,1993$

41) Robertson BH, D'Hondt EH, Spelbring J, et al: Effect of postexposure vaccination in a 
chimpanzee model of hepatitis A virus infection. J Med Virol 43:249-251, 1994

42) D'Hondt E, Purcell RH, Emerson SU, et al : Efficacy of an inactivated hepatitis A vaccine in pre- and postexposure conditions in marmosets. J Infect Dis 171 (Suppl 1) : S40-43, 1995

43) Masterton RG, Strike PW, Tettmar RE : Hepatitis A immunity and travel history. J Infect $23: 321-326,1991$

44) Bader TF : Hepatitis A vaccine. Am J Gastroenterol 91:217-222, 1996

45) Innis BL, Snitbhan R, Kunasol P, et al : Protection against hepatitis $\mathrm{A}$ by an inactivated vaccine. JAMA 271:1328-1334, 1994
46) Werzberger A, Mensch B, Kuter B, et al: A controlled trial of a formalin-inactivated hepatitis A vaccine in healthy children. N Engl J Med 327 : 453-457, 1992

47) Berger R, Just M : Vaccination against hepatitis A : Control 3 years after the first vaccination. Vacccine $10: 295,1992$

48) Koff RS : Risks associated with hepatitis A and hepatitis B in patients with hepatitis C. J Clin Gastroenterol $33: 20-26,2001$

49) Poovorawan Y, Theamboonlers A, Chumdermpadetsuk S, et al : Safety, immunogenicity, and kinetics of the immune response to a single dose of virosome-formulated hepatitis A vaccine in Thais. Vaccine $13: 891-893,1995$ 